\title{
Corporate Ratings and a Model Proposition for the Manufacturing Industry at Borsa Istanbul
}

\author{
Nurcan Öcal ${ }^{1}$, Metin Kamil Ercan ${ }^{2} \&$ Eyüp Kadıŏglu ${ }^{1}$ \\ ${ }^{1}$ Capital Markets Board of Turkey, Ankara, Turkey \\ 2 Department of Business Administration, Gazi University, Ankara, Turkey \\ Correspondence: Eyüp Kadığlu, Capital Markets Board of Turkey, Eskisehir Yolu 8. Km No: 156, Ankara, Turkey. \\ E-mail: eyup.kadioglu@gmail.com
}

Received: April 20, 2015

Accepted: May 5, 2015

Online Published: May 25, 2015

doi:10.5430/ijfr.v6n3p13

URL: http://dx.doi.org/10.5430/ijfr.v6n3p13

\begin{abstract}
In this study it is aimed to develop a model using logistic regression analysis for the forecasting the rating grade of a manufacturing firm that form the basis to expert evaluation. Under the scope of this study 35 financial ratios are used as the independent variables, which are calculated on the grounds of annual financial statements and their notes during the period of 2007-2013 which are disclosed by the 206 listed manufacturing firms on Borsa Istanbul, and the status of the firms being "good" or "bad" based on financial capability is used as the dependent variable. Percentage of correct classification of developed model is at acceptable levels. By using the developed model, probability of a firm being "good" or "bad" can be estimated and using the proposed scale rating grade can be appointed of the firm that rating wanted to be performed.
\end{abstract}

Keywords: corporate rating, logistic regression analysis, rating, financial failure, Borsa Istanbul

\section{Introduction}

Rating agencies have been criticized severely due to recent bankruptcies and financial crisis. The critics have been focusing on the inadequate regulations at the national and international level and rating agencies have been criticized on losing impartiality, giving better or worse grades than what is deserved. However, taking increment in number of issuers, securitizations and complexity of financial instruments and level of globalization into consideration, it is clear that the importance of rating activities have gradually increased from the point of market and market participants (Öcal, 1997). In this manner, it is thought that the rating agencies will continue to exist and operate in the market.

According to US Securities and Exchange Commission (SEC), credit rating is an opinion of rating agency at a specific date regarding the solvency of a firm or of the security or the bond of the firm (SEC, January 2003).

Capital Markets Board of Turkey (CMB) defined credit rating as "credit rating an independent, impartial and fair evaluation and classification of the riskiness and solvency of institutions or the ability to pay the capital, interest, and other obligations regarding capital market instruments representing debt, within the specified term by rating agencies."

According to Banking Regulation and Supervision Agency (BRSA) of Turkey, rating is a process of determining creditworthiness and accordingly credit note, based on the result of studies and analyses to be made depending on the nature of such activities, of customers that are in the scope. Additionally, rating of creditworthiness is defined as operation of an authorized rating agency regarding the independent, impartial and fair evaluation, classification and convenient rating of customer's capability of repaying credits that are to be used or customer's risk of being able to meet obligations of the concerning market instruments which represent their indebtedness such as principal, interest and the likewise.

As seen from the definitions, rating can be done for the firm as a whole or for the particular capital market instruments representing the debt or solvency and the rating activity shall be independent and impartial. 
On the other hand, there is no single procedure regarding rating methodology. Each rating agency has its own unique methodology and the methodology can be differentiated in itself by sectors, type of firm and type of financial instrument.

Using statistical methods solely while carrying out rating activities have been criticized. On the other hand, as rating based on solely experts' judgments, can be a waste of time and resource and as they are open to human error and have potential deviation from objectivity, the benefits of using statistical methods come into prominence. However it shall not be assumed that using only statistical methods are adequate. Accordingly, the critique of statistical methods shall be considered as well. Therefore statistical techniques and experts' judgments shall be used jointly in order to remove the limitation of a human, selecting data, processing and concluding with a result from a wide range of data and inadequacy of non-numeric data processing of statistical models shall be eliminated.

In this study it is aimed to develop a model using logistic regression analysis for the forecasting the rating grade of the manufacturing firms that will form basis to Expert evaluation. It should be kept in mind that the rating grade that will be determined by the developed model, is not final.

Furthermore, the rating requires usage of non-public data and/or information besides public data and/or information. In this study, only public data and/or information of the firms are used.

Examining especially some foreign studies, it is understood that rating grades that are given by independent rating agencies are used as dependent variable and therefore dependent variable is considered depending on number of rating grades. In Turkey, since the rating is not compulsory, and optional/voluntary, rating results are not disclosed to public unless they are adequate, usage of rating grades that are determined by rating agencies as dependent variable are not sufficient to run the analysis. Therefore our dependent variable that is used in this study constitutes from two groups (the status of the firms being "good" or "bad" due to financial capability).

Overviewing studies in this area it is seen that discriminant analysis highly used at early times. Afterwards, probit and logit analysis have been started to be used and it is understood that analysis based on "artificial intelligent" have started to be used in some of the latest studies.

In our study, instead of running highly used discriminant analysis which break the assumption of normal distribution, continuity and equality of the deviation matrix, logistic regression analysis is used which gives better results than discriminant analysis and gives opportunity to classify results by producing different probability values for each observation.

Reviewing the rating studies that are conducted in Turkey, no prior study that used same methodology, data and period is found.

Under the scope of this study 35 financial ratios are used as the independent variables, which are calculated on the grounds of annual financial statements and their notes during the period of 2007-2013 which are disclosed by the 206 listed manufacturing firms on Borsa Istanbul equity market.

In this study, the status of the 206 firms being "good" or "bad" based on financial capability is collected by searching news and disclosures at Borsa Istanbul web site for the period of 2007-2009 and Public Disclosure Platform (PDP) web site for the period of 2010-2013. To identify "good" or "bad", all news and disclosures of sample firms is evaluated by taking into consideration the information about market changes and delisting made by Borsa Istanbul on PDP. Delisted firms or firms those trading activities are held due to financial distress, firms that changed trading market (in negative manner), firms obliged monthly declaration due to financial distress, firms that are warned to take measures by CMB or Borsa Istanbul due to losing capital, or the firms that applied to court by itself due to financial distress are counted as "bad" and crated unique data. This manually created data makes our study original and contributing.

Abstract of the studies regarding the rating activities and methods that are used is stated under the second section of our study, where the data and the method that is used in this study is stated under third and findings that are received and interpretations of them are stated under the fourth section of our study. Finally the conclusion part is stated under the last section.

\section{Literature Review}

Some of the main studies and methodologies on corporate rating are summarized as follows. The studies which are conducted by using ordinary statistical methods are summarized in Table 1 and the studies which are conducted by using artificial intelligent based analysis are summarized in Table 2 (Hajek, 2010). 
Table 1. Prior studies using statistical methods

\begin{tabular}{|c|c|c|c|c|c|}
\hline Studies & Methods & $\begin{array}{l}\text { Number } \\
\text { of Classes }\end{array}$ & Data Set & $\begin{array}{c}\text { Number of } \\
\text { Input Variables }\end{array}$ & $\begin{array}{c}\text { Classification } \\
\text { Accuracy on } \\
\text { Testing Data (\%) }\end{array}$ \\
\hline Horrigan (1966) & Linear Regression & 9 & 200 & 6 & 56.0 \\
\hline West (1970) & Linear Regression & 9 & - & 4 & 62.0 \\
\hline $\begin{array}{l}\text { Pinches and Mingo } \\
\text { (1973 and 1975) }\end{array}$ & Mult. Discriminant Analy. & 5 & 180 & 6 & 64.6 \\
\hline Kaplan and Urwitz & Ordered Probit Model & 6 & 207 & 10 & 66.0 \\
\hline (1979) & Linear Regression & 6 & 207 & 10 & 55.0 \\
\hline $\begin{array}{c}\text { Altman and Katz } \\
\text { (1976) }\end{array}$ & Mult. Discriminant Analy. & 2 & - & 14 & 77.0 \\
\hline $\begin{array}{l}\text { Pogue and Soldofsky } \\
\text { (1969) }\end{array}$ & Linear Regression & 2 & 113 & 5 & 80.0 \\
\hline \multirow{6}{*}{$\begin{array}{l}\text { Kamstra, Kennedy } \\
\text { and Suan (2001) }\end{array}$} & Ordered Logistic Regression & 6 & 89 & 5 & 58.4 \\
\hline & Ordered Logistic Regression & 6 & 265 & 5 & 47.5 \\
\hline & Mult. Discriminant Analy. & 6 & 89 & 5 & 62.9 \\
\hline & Mult. Discriminant Analy. & 6 & 265 & 5 & 41.9 \\
\hline & Linear Regression & 6 & 89 & 5 & 52.8 \\
\hline & Linear Regression & 6 & 265 & 5 & 38.9 \\
\hline $\begin{array}{l}\text { Hwang and Cheng } \\
\text { (2008) }\end{array}$ & Ordered Logistic Regression & 3 & 736 & 24 & 72.8 \\
\hline
\end{tabular}

Table 2. Prior studies using artificial intelligence methods

\begin{tabular}{|c|c|c|c|c|c|}
\hline Studies & Methods & $\begin{array}{l}\text { Number of } \\
\text { Classes }\end{array}$ & Data Set & $\begin{array}{c}\text { Number of Input } \\
\text { Variables. }\end{array}$ & $\begin{array}{c}\text { Classification } \\
\text { Accuracy on } \\
\text { Testing Data (\%) }\end{array}$ \\
\hline \multirow{4}{*}{$\begin{array}{l}\text { Moody and Utans } \\
\text { (1995) }\end{array}$} & Feed-Forw. Neu. Netw. & 16 & 196 & 10 & 36.2 \\
\hline & Feed-Forw. Neu. Netw. & 5 & 196 & 10 & 63.8 \\
\hline & Feed-Forw. Neu. Netw. & 3 & 196 & 10 & 85.2 \\
\hline & Mult. Discriminant Analy. & 16 & 196 & 10 & 21.4 \\
\hline \multirow{2}{*}{$\begin{array}{l}\text { Dutta and Shekhar } \\
\text { (1988) }\end{array}$} & Feed-Forw. Neu. Netw. & 2 & 47 & 10 & 83.3 \\
\hline & Multiple Linear Regr. & 2 & 47 & 10 & 64.7 \\
\hline \multirow{2}{*}{$\begin{array}{l}\text { Singleton and Surkan } \\
\text { (1990 and 1995) }\end{array}$} & Feed-Forw. Neu. Netw. & 2 & 18 & 8 & 88.0 \\
\hline & Mult. Discriminant Analy. & 2 & 18 & 8 & 39.0 \\
\hline \multirow{2}{*}{$\begin{array}{l}\text { Brennan and Brabazon } \\
\text { (2004) }\end{array}$} & Feed-Forw. Neu. Netw. & 2 & 600 & 8 & 84.0 \\
\hline & Feed-Forw. Neu. Netw. & 5 & 791 & 8 & 52.7 \\
\hline $\begin{array}{c}\text { Delahunty and } \\
\text { OCallaghan (2004) }\end{array}$ & Artificial Intel. Systems & 2 & 791 & 8 & 72.5 \\
\hline \multirow{3}{*}{$\begin{array}{c}\text { Brabazon and O’Neill } \\
\text { (2006) }\end{array}$} & Grammatical Evolution & 2 & 791 & 8 & 84.9 \\
\hline & Feed-Forw. Neu. Netw. & 2 & 791 & 8 & 83.3 \\
\hline & Mult. Discriminant Analy. & 2 & 791 & 8 & 85.2 \\
\hline \multirow{3}{*}{$\begin{array}{l}\text { Garavagia (1991) } \\
\text { Kim (2005) }\end{array}$} & Feed-Forw. Neu. Netw. & 3 & 797 & 87 & 84.9 \\
\hline & Adaptive Learning Netw. & 4 & 1080 & 26 & 83.8 \\
\hline & Feed-Forw. Neu. Netw. & 6 & 299 & 5 & 66.7 \\
\hline \multirow[t]{2}{*}{ Maher and Sen (1997) } & Mult. Discriminant Analy. & 6 & 299 & 5 & 61.0 \\
\hline & Ordered Logistic Regr. & 6 & 299 & 5 & 61.7 \\
\hline \multirow{4}{*}{ Huang and Chen (2004) } & Feed-Forw. Neu. Netw. & 5 & 265 & 5 & 80.0 \\
\hline & Feed-Forw. Neu. Netw. & 5 & 265 & 12 & 79.3 \\
\hline & Support Vector Machine & 5 & 265 & 5 & 78.9 \\
\hline & Support Vector Machine & 5 & 265 & 12 & 80.0 \\
\hline \multirow{3}{*}{ Kim (1993) } & Feed-Forw. Neu. Netw. & 6 & 228 & 8 & 55.2 \\
\hline & Rule Based Expert System & 6 & 228 & 8 & 31.0 \\
\hline & Linear Regression & 6 & 228 & 8 & 36.2 \\
\hline
\end{tabular}




\begin{tabular}{cccccc} 
& Mult. Discriminant Analy. & 6 & 228 & 8 & 36.2 \\
& Ordered Logistic Regr. & 6 & 228 & 8 & 43.1 \\
Feed-Forw. Neu. Netw. & 6 & 120 & 8 & 56.7 \\
$\begin{array}{c}\text { Chaveesuk and } \\
\text { Srivaree-Ratana } \\
\text { (1999) }\end{array}$ & Radial Basis Function Neural & 6 & 120 & 8 & 38.3 \\
& Network & & & 36.7 \\
\hline
\end{tabular}

The variables and their definitions that used on related previous studies are given in Table 3 (Hajek, 2010).

Table 3. Input variables used for corporate credit ratings in prior studies

\begin{tabular}{|c|c|}
\hline es & Input Variables \\
\hline Horrig & $\begin{array}{l}\text { sets, Net Worth/Total Depts, Operating Margin, Working Capital/Sales, Sales/Net } \\
\text { ubordination status }\end{array}$ \\
\hline Wes & out Loss in Years, Market Value/Total Depts, Market Value \\
\hline $\begin{array}{l}\text { Pinches anc } \\
(1973 \text { and }\end{array}$ & $\begin{array}{l}\text { ars of Consecutive Dividends, Issue Size, ((Net Income+Interest)/Interest, Subordinat } \\
\text { tus, Long-Term Debts/ Total Assets, Net Income/ Total Assets }\end{array}$ \\
\hline $\begin{array}{l}\text { Kaplan and Urwitz } \\
\text { (1979) }\end{array}$ & $\begin{array}{l}\text { sh Flow/Interest, Cash Flow/Total Debt, Long-Term Debts/Total Assets, Long-Term } \\
\text { ebts/Net Worth, Net Income/Total Assets, Total Assets, Issue Size, Total Assets Variation, } \\
\text { t Income Variation, Subordination Status }\end{array}$ \\
\hline Altman and Katz (1976) & $\begin{array}{l}\text { riation, Cash Flow, Earnings Variation, Return on } \\
\text { n/Operating Revenue }\end{array}$ \\
\hline Pogue and Soldofsky (1969) & e/Total Assets, Net Income Variation/Total Assets, Total \\
\hline $\begin{array}{r}\text { Kamstra, Kenı } \\
(20\end{array}$ & $\begin{array}{l}\text { sets, Subordination Status, Return on Total Assets, Total Debts / Total Assets, Interest } \\
\text { e }\end{array}$ \\
\hline $\begin{array}{r}\text { Hwang a } \\
(20\end{array}$ & $\begin{array}{l}\text { KMV-Merton Default Probability, Market Equity Value, Earnings, Total Assets, Total } \\
\text { Debts/(EBIT+ Depreciation + Amortization), Total Assets /Equity, Long-Term Debts/Total } \\
\text { Capital, Short-Term Debt/Total Capital, Interest Coverage, ( EBIT+ Depreciation plus } \\
\text { Amortization)/Interest, Cash Flow, Interest, Net Income, Return on Capital, Return on Equity, } \\
\text { Return on Total Assets, Operating Margin, Retained Earnings/ Total Assets, Current Ratio, } \\
\text { Quick Ratio, Cash Ratio }\end{array}$ \\
\hline $\begin{array}{l}\text { Dutta and Shekhar } \\
\text { (1988) }\end{array}$ & $\begin{array}{l}\text { Total Liabilities/Cash Assets, Total Debt/Total Assets, Sales/Net Worth, Return on Sales, } \\
\text { Financial Strength, Earnings/Fixed Cost, Five Years Revenue Growth Rate, Working } \\
\text { Capital/Sales, Subjective Prospect of Firm, Total Revenue Ratio, }\end{array}$ \\
\hline $\begin{array}{r}\text { Single } \\
(199\end{array}$ & $\begin{array}{l}\text { ng-Term Debts/Total Capital, Interest Coverage, Return on Equity, Five Years Return on } \\
\text { uity Variation, Total Assets, Construction Costs/Cash Flow } \\
\text { rrent Ratio, Retained Earnings/Total Assets, Interest Coverage, }\end{array}$ \\
\hline Bre & $\begin{array}{l}\text { al Debt/Total Assets, Net Margin, Market to Book Value, Total Assets, Return on Total } \\
\text { ets }\end{array}$ \\
\hline $\begin{array}{l}\text { Delahunty and OCalla } \\
\qquad(2004)\end{array}$ & $\begin{array}{l}\text { th Ratio, Retained Earnings/Total Assets, Interest Coverage, Total Debt/Total Assets, Net } \\
\text { n, Market to Book Value, Total Assets, Return on Total Assets }\end{array}$ \\
\hline Brabazon and O'Neill (2006) & $\begin{array}{l}\text { Current Ratio, Retained Earnings/Total Assets, Interest Coverage, Total Debt/Total Assets, Net } \\
\text { Margin, Market to Book Value, Total Assets, Return on Total Assets } \\
\text { Total Assets, Current Ratio, Return on Total Assets, Total Debt/Total Assets, Sales/Fixed }\end{array}$ \\
\hline Kim & $\begin{array}{l}\text { ts, Operating Margin, Interest Coverage, Long-Term Debts/Total Capital, Cash } \\
\text { //Current Liabilities }\end{array}$ \\
\hline her & 1 Debt /Total Assets, $\mathrm{Ne}$ \\
\hline Huang and Chen (2004) & Ig-Term Debts / Total Capital, Total Debt /Total Assets, \\
\hline $\mathrm{K}$ & $\begin{array}{l}\text { g-Term Debts/Total Capital, Current Ratio, (Net Income+ } \\
\text { idends, Stock Price, Subordination Status }\end{array}$ \\
\hline $\begin{array}{r}\text { Chaveesuk and } \\
(1 S\end{array}$ & $\begin{array}{l}\text { otal Assets, Total Debt, Long-Term Debts/Total Capital, Short-Term Debt/Total Capital, } \\
\text { urrent Ratio, (Net Income+ Interest)/Interest, Total Debt/Total Assets, Return on Sales }\end{array}$ \\
\hline
\end{tabular}


As the number of variables increase in analysis, the interpretation of model becomes more difficult and applicability of model decreases. Therefore the elimination of insignificant or non-explanatory variables in models should be done. In case of high correlation between variables, it is possible to decrease number of variables by using variable selection methods. On the other hand, this approach may cause excluding important or significant variables from the model due to election criteria (Özdinç, 1999).

Some studies on rating have also conducted in Turkey last decades. The main difference between this domestic and international studies arises from dependent variable of models. Except for rating on banks, as the firm does not have rating or disclosed rating grades in Turkey the rating grades of firms cannot be used as a dependent variable. Some of the related studies on rating in Turkey can be summarized as in Table 4.

Table 4. Related studies carried out in Turkey

\begin{tabular}{|c|c|c|c|c|c|}
\hline $\begin{array}{c}\text { Authors } \\
\text { (Year) }\end{array}$ & Methods & Data & $\begin{array}{c}\text { Dependent } \\
\text { Variables } \\
\end{array}$ & $\begin{array}{c}\text { Independent } \\
\text { Variables } \\
\end{array}$ & Results \\
\hline Özdinç (1999) & $\begin{array}{l}\text { Logistic Regression } \\
\text { (Grouping } \\
\text { Discriminant and } \\
\text { MANOVA at first), }\end{array}$ & $\begin{array}{l}136 \text { firms/ } \\
1993\end{array}$ & $\begin{array}{c}\text { The result of } \\
\text { Discriminant } \\
\text { Analysis }\end{array}$ & $\begin{array}{l}9 \text { Financial } \\
\text { Ratios }\end{array}$ & $\begin{array}{c}\text { Classification of } \\
\text { correctness of Logit is } \\
94.9 \%\end{array}$ \\
\hline $\begin{array}{l}\text { Boyacioğlu } \\
\text { (2003) }\end{array}$ & $\begin{array}{l}\text { Logistic Regression, } \\
\text { Artificial Neural } \\
\text { Netw., } \\
\text { Discriminant } \\
\text { Analysis, } \\
\text { Cluster Analysis }\end{array}$ & $\begin{array}{c}14 \text { banks/ } \\
1996-2000\end{array}$ & $\begin{array}{l}\text { Rating } \\
\text { grades }\end{array}$ & $\begin{array}{l}24 \text { Financial } \\
\text { Ratios }\end{array}$ & $\begin{array}{l}\text { Artificial Neural Network } \\
\text { method has better } \\
\text { explanatory power than } \\
\text { others }\end{array}$ \\
\hline $\begin{array}{l}\text { Tatlıdil and } \\
\text { Ozel (2005) }\end{array}$ & $\begin{array}{c}\text { Discriminant } \\
\text { Analysis, } \\
\text { Logistic Regression }\end{array}$ & 38 firms/ 2001 & $\begin{array}{l}\text { Problem in } \\
\text { solvency }\end{array}$ & $\begin{array}{l}6 \text { Financial } \\
\text { Ratios }\end{array}$ & The model is not usable \\
\hline Sezgin (2006) & $\begin{array}{l}\text { Logistic Regression, } \\
\text { Probit Regression, } \\
\text { Discriminant } \\
\text { Analysis, } \\
\text { Classification and } \\
\text { Regression Trees }\end{array}$ & 1649 firms & $\begin{array}{l}\text { Problem in } \\
\text { solvency }\end{array}$ & & $\begin{array}{l}\text { Classification and } \\
\text { Regression Trees are } \\
\text { better than others }\end{array}$ \\
\hline İşman (2009) & $\begin{array}{l}\text { Analytic Hierarchy } \\
\text { Process }\end{array}$ & 3 car firms & & $\begin{array}{l}\text { Expert's } \\
\text { Opinion }\end{array}$ & \\
\hline $\begin{array}{l}\text { Yolaş Vurur } \\
\text { (2009) }\end{array}$ & Logistic Regression & $\begin{array}{l}4937 \mathrm{firm} / \\
2005-2007\end{array}$ & $\begin{array}{l}3 \text { year ave. } \\
\text { Profit is over } \\
\text { Price Index } \\
\text { or not }\end{array}$ & $\begin{array}{l}5 * \text { Financial } \\
\text { Ratios }\end{array}$ & $\begin{array}{c}\text { Classification of } \\
\text { correctness is } 64.21 \%\end{array}$ \\
\hline Hazar (2009) & $\begin{array}{l}\text { Factor Analysis } \\
\text { Panel Regression }\end{array}$ & $\begin{array}{l}10 \text { banks/ } \\
2004-2007\end{array}$ & $\begin{array}{l}\text { Rating } \\
\text { grades }\end{array}$ & $\begin{array}{l}15 * \text { Financial } \\
\text { Ratios }\end{array}$ & $\begin{array}{c}\text { Result are consistent with } \\
\text { independent rating } \\
\text { agencies grades }\end{array}$ \\
\hline Yüce (2011) & $\begin{array}{l}\text { Ordered Logit, } \\
\text { Artificial Neural } \\
\text { Network }\end{array}$ & $\begin{array}{c}40 \text { firms/ } \\
1998-2009\end{array}$ & $\begin{array}{l}\text { Current } \\
\text { ratios }\end{array}$ & $\begin{array}{l}4 \text { Financial } \\
\text { Ratios }\end{array}$ & $\begin{array}{c}\text { Artificial Neural Network } \\
\text { method has better } \\
\text { explanatory power than } \\
\text { Ordered Logit method. }\end{array}$ \\
\hline $\begin{array}{c}\text { Budak ve } \\
\text { Erpolat (2012) }\end{array}$ & $\begin{array}{l}\text { Logistic Regression } \\
\text { Artificial Neural } \\
\text { Network }\end{array}$ & 1639 person & $\begin{array}{l}\text { Problem in } \\
\text { solvency }\end{array}$ & $\begin{array}{l}\text { Loan Amount, } \\
\text { Term, Monthly } \\
\text { Income, Pledges } \\
\text { and Mortgages, } \\
\text { Occupation, Age } \\
\text { and Marital } \\
\text { status }\end{array}$ & $\begin{array}{l}\text { Classification of } \\
\text { correctness of Logit is } \\
65.4 \% \text { and } \\
\text { classification of } \\
\text { correctness of Artificial } \\
\text { Neural Network is } 70.3 \%\end{array}$ \\
\hline $\begin{array}{l}\text { Uzunoğlu } \\
\text { (2013) }\end{array}$ & $\begin{array}{l}\text { Artificial Neural } \\
\text { Network }\end{array}$ & $\begin{array}{l}16 \text { banks/ } \\
2004-2011\end{array}$ & $\begin{array}{l}\text { Rating } \\
\text { grades }\end{array}$ & Financial Ratios & $\begin{array}{c}100 \% \text { learning success and } \\
80 \% \text { testing success }\end{array}$ \\
\hline
\end{tabular}

Note: $(*)$ Number of variables is used in final model. 
In rating activities both quantitative data (financial ratios) and qualitative information shall be taken into consideration. Qualitative informations may enter to the model as a dummy variable or as an expert's judgment. It is argued that using dummy variable for qualitative data is a more appropriate way and it is seen as increasing the success of the model. For example, delay in disclosure of financial reports, independent audit opinion, age of firm, number of employee at managing level, the duration of work of the managers in the firm, the mortgage on the firms' assets may be included to model as the dummy variables. Expert's judgment may include fairness and correctness financial reports and data of the firm, since financial reports and data of the firm had been manipulated (Kadıoglu, 2014). Keasey and Watson (1997) argues that including qualitative information to model as the dummy variables will increase the success of forecasting financial failure in small and middle sized firms.

\section{Data and Methodology}

In this study, annual financial statements and their notes of firms that conduct their activities in manufacturing sector and which are prepared according to International Financial Reporting Standards (IFRS) regarding the 2007-2013 period are used. The 206 listed manufacturing firms on Borsa Istanbul equity market have selected as sample and their publicly disclosed balance sheets, income statements and cash flow statements and their notes were collected by using Finnet Analysis Program and from Borsa Istanbul web site (for 2007-2009) and PDP (for 2010-2013) web site.

Due to data prepared, 35 financial ratios in 5 groups were calculated that may have an effect on solvency of the firms. While determining the financial ratios that serve basis to independent variable of this study, the ratios that are used prior studies were also taken into consideration. Additionally, as IFRS was in force during the period of examination, it became possible for us to use the information that obtained from cash flow from operating and investing activities and foreign exchange position which weren't taken into consideration by prior studies conducted in Turkey.

The financial ratios that are prepared to be used within the scope of the study and their definitions are as follows.

Table 5. Financial ratios and their definitions used in the study

\begin{tabular}{|c|c|c|}
\hline Number & $\begin{array}{c}\text { Independent } \\
\text { Variables }\end{array}$ & Definitions \\
\hline \multicolumn{3}{|c|}{ Financial ratios using to measure relation between profit and sales } \\
\hline 1 & KSA1 & Gross Margin / Net Sales \\
\hline 2 & KSA2 & Operating Profit / Net Sales \\
\hline 3 & KSA3 & Profit Before Tax / Net Sales \\
\hline 4 & KSA4 & Net Profit / Net Sales \\
\hline 5 & KSA5 & Earnings Before Interest and Taxes (EBIT) / Net Sales \\
\hline 6 & KSA6 & Earnings Before Interest, Taxes, Depreciation and Amortization I / Net Sales \\
\hline 7 & KSA7 & Earnings Before Interest, Taxes, Depreciation and Amortization II ${ }^{1} /$ Net Sales \\
\hline \multicolumn{3}{|c|}{ Financial ratios using to measure relation between profit and equity } \\
\hline 8 & KSE1 & Profit Before Tax / Total Equity \\
\hline 9 & KSE2 & Profit After Tax / Total Equity \\
\hline 10 & KSE3 & Profit After Tax / Total Assets \\
\hline 11 & KSE4 & Earnings Before Interest and Taxes / Total Assets \\
\hline 12 & KSE5 & Earnings Before Interest, Taxes, Depreciation and Amortization I / Total Assets \\
\hline 13 & KSE6 & Earnings Before Interest, Taxes, Depreciation and Amortization II / Total Assets \\
\hline \multicolumn{3}{|c|}{ Financial ratios using to measure debt covering } \\
\hline 14 & BK1 & Interest Coverage (Earnings Before Interest and Taxes / Interest Expense) \\
\hline 15 & BK2 & $\begin{array}{l}\text { Earnings Before Interest, Taxes, Depreciation and Amortization / (Interest Expense }+ \text { Current } \\
\text { Portion of Long Term Debts) }\end{array}$ \\
\hline 16 & BK3 & Total Liabilities / Earnings Before Interest, Taxes, Depreciation and Amortization II \\
\hline 17 & BK4 & Assets in Foreign Currency / Liabilities in Foreign Currency \\
\hline 18 & BK5 & Cash Flows from Operating Activities / Total Liabilities \\
\hline 19 & BK6 & Cash Flows from Operating Activities / (Total Equity + Total Liabilities) \\
\hline 20 & BK7 & Cash Flows from Operating and Investment Activities / Total Equity \\
\hline \multicolumn{3}{|c|}{ Financial ratios are using to analyze capital structure } \\
\hline 21 & SY1 & Total Liabilities / Total Equity \\
\hline 22 & SY2 & Leverage Ratio (Total Liabilities / Total Assets) \\
\hline
\end{tabular}




\begin{tabular}{|c|c|c|}
\hline 23 & SY3 & Tangible Fixed Assets (Net) / Total Equity \\
\hline 24 & SY4 & $\begin{array}{l}\text { Equity Structure ((Shareholder's Equity + Capital Reserves + Revenue Restrictive Reserves / } \\
\text { Total Equity) }\end{array}$ \\
\hline \multicolumn{3}{|c|}{ Financial ratios using to analyze liquidity } \\
\hline 25 & L1 & Current Ratio (Current Assets / Short Term Liabilities) \\
\hline 26 & $\mathrm{~L} 2$ & $\begin{array}{l}\text { Liquidity Ratio (Liquid Assets }+ \text { Securities }+ \text { Short Term Receivable / Short Term } \\
\text { Liabilities) }\end{array}$ \\
\hline 27 & L3 & $\begin{array}{l}\text { Inventory Dependency Rate (Short Term Liabilities - (Liquid Assets + Quick Assets)) / } \\
\text { Inventories) }\end{array}$ \\
\hline 28 & L4 & Net Sales / Short Term Liabilities \\
\hline 29 & L5 & Profit After Tax / Short Term Liabilities \\
\hline 30 & L6 & Receivables Turnover Rate (Net Sales / Trade Receivables) \\
\hline 31 & L7 & Inventory Turnover Rate (Cost of Sales / Inventories) \\
\hline 32 & L8 & Effectiveness Rate $(1 /((1+$ Receivables Turnover Rate $)+(1+$ Inventory Turnover Rate $))$ \\
\hline 33 & L9 & Working Capital Turnover Rate (Net Sales / Current Assets) \\
\hline 34 & L10 & Assets Turnover Rate (Net Sales / Total Assets) \\
\hline 35 & L11 & Debts Turnover Rate (Cost of Sales / Trade Debts) \\
\hline
\end{tabular}

Since there is no rating obligation for Turkish firms except for banks, it is not possible use rating notes as the dependent variable that are given by independent rating agencies. Therefore in this study, the status of the companies being "good" or "bad" based on financial capability is used as the dependent variable. In other words, if the firm is financially in a bad situation or in case of failure then dependent variable takes the value of " 0 " and otherwise it takes the value of "1".

According to Özdemir (2011), quantitative and qualitative indicators can be used in the determination of financial failure and quantitative indicators can be classified as the book value based indicators and market value based indicators.

In the case of using qualitative indicators, determining the class of the firm is easier and market value based indicators give more fair and accurate results when the market is efficient (Özdemir, 2011). Taking consider Özdemirs' idea into account, we used qualitative indicators to classify bad or good firms ${ }^{2}$.

For this manner, the status of the 206 companies being "good" or "bad" based on financial capability is collected by searching news and disclosures at Borsa Istanbul web site for the period of 2007-2009 and KAP web site for the period of 2010-2013. To identify "good" or "bad", we searched all news and disclosures of sample firms by taking into consideration following criteria and the firm, matched following criteria, is classified as "bad" firm.

i) Firms that are delisted by Borsa Istanbul due to financial distress,

ii) Firms those trading activities are held by Borsa Istanbul due to financial distress,

iii) Firms those trading market are lowered by Borsa Istanbul,

iv) Firms that are obliged monthly declaration due to financial distress,

v) Firms that are warned by CMB or Borsa Istanbul to take measures to recover the capital,

vi) Firms that are applied to court by the firm itself due to financial distress.

The firm, being "bad", is checked yearly bases and whenever the information stated above is disseminated we accepted that year as the starting year for "bad" for the firm. If the firm counted as "bad" and if there is new reversal information in following years then we changed the firm as "good".

Depending on financial distress, being "good" or "bad" is constitute our dependent variable and it takes value of "1" for "good" and " 0 " for "bad".

In our data outliers and having much missing observations have been eliminated by basic sorting and filtering applications. Additionally, since the base of the number is different, all independent variables normalized by subtracting mean and dividing to standard deviation. As result, $88.5 \%$ (1149 observations) of total sample (1298 observations) is classified as "good" and $11.5 \%$ (149 observations) of total sample is classified as "bad".

To avoid weakness and critics on discriminant analysis and least square regression (not fulfilling normal distribution assumptions), we chose logistic regression to run for our model. The studies also show that logistic regression gives 
better results in case of dependent variable is discrete. Furthermore in our case, logistic regression gives different probability values for each observation depending on the variables in the model and this enable us to determine rating notes depending on tranches of probability.

In our logistic regression analysis, SPSS 18 Portable and SPSS Clementine 11 software packages have been used.

The classification studies on unbalanced data such as an unequal number of "bad" and "good" observation has the disadvantages. Because, it is argued that correct classification success for proportionally high number of observations (in our case being "good") is higher than correct classification success for proportionally lower number of observations (in our case being "bad"). It is also the case for our sample. In order to overcome this biasness, we run the analysis on balanced sample. In our study, to create balanced sample we took all "bad" observations and randomly selected $15 \%$ of "good" observations by using SPSS Clementine 11 software. At the end, our subsample consist of $49 \%$ of "bad" observations and 51\% of "good" observations and total subsample size became 306 observations. In order to use as much as observations, we designed to our sample consisting $49 \%$ "bad" and 51\% "good" observations. The descriptive statistics of variables are given Table 6.

Table 6. Descriptive statistics

\begin{tabular}{|c|c|c|c|c|c|c|c|}
\hline & Variables & Min. & Max. & Mean & St. Dev. & Skewness & Kurtosis \\
\hline 1 & GOOD1BAD0 & 0.00 & 1.00 & 0.50 & 0.50 & 0.00 & -2.02 \\
\hline 2 & KSa1 & -1.60 & 1.00 & 0.15 & 0.22 & -3.04 & 23.04 \\
\hline 3 & $\mathrm{KSa} 2$ & -248.46 & 2.73 & -1.36 & 16.18 & -14.33 & 214.88 \\
\hline 4 & KSa3 & -224.32 & 3.08 & -1.28 & 14.30 & -14.98 & 232.50 \\
\hline 5 & KSa4 & -262.59 & 2.60 & -1.32 & 16.40 & -15.80 & 252.40 \\
\hline 6 & KSa5 & -245.29 & 2.34 & -1.34 & 15.99 & -14.30 & 213.92 \\
\hline 7 & KSa6 & -6.20 & 2.13 & -0.01 & 0.53 & -7.57 & 82.78 \\
\hline 8 & $\mathrm{KSa} 7$ & -6.20 & 0.93 & -0.01 & 0.51 & -8.64 & 93.71 \\
\hline 9 & KSe1 & -8.54 & 42.37 & 0.14 & 2.85 & 12.65 & 186.88 \\
\hline 10 & KSe2 & -8.63 & 42.93 & 0.12 & 2.87 & 12.82 & 190.85 \\
\hline 11 & KSe3 & -4.45 & 6.81 & -0.03 & 0.54 & 5.54 & 113.58 \\
\hline 12 & KSe4 & -2.97 & 6.80 & 0.03 & 0.48 & 9.70 & 155.57 \\
\hline 13 & KSe5 & -0.96 & 0.74 & 0.05 & 0.12 & -1.54 & 23.28 \\
\hline 14 & KSe6 & -0.96 & 0.78 & 0.05 & 0.12 & -1.40 & 23.47 \\
\hline 15 & BK1 & -1926.04 & 65.03 & -13.96 & 138.48 & -11.77 & 151.25 \\
\hline 16 & BK2 & -910.75 & 174.02 & -2.58 & 60.79 & -13.08 & 194.32 \\
\hline 17 & BK3 & -997.42 & 889.69 & 2.47 & 124.11 & 0.38 & 33.51 \\
\hline 18 & BK4 & 0.00 & 1450.20 & 8.73 & 94.56 & 14.74 & 224.05 \\
\hline 19 & BK5 & -2.67 & 3.76 & 0.02 & 0.54 & 0.07 & 14.62 \\
\hline 20 & BK6 & -1.21 & 0.72 & -0.01 & 0.20 & -2.28 & 11.44 \\
\hline 21 & BK7 & -3.96 & 3.33 & -0.06 & 0.65 & -1.04 & 10.75 \\
\hline 22 & SY1 & -111.11 & 188.50 & 1.13 & 14.59 & 6.16 & 117.53 \\
\hline 23 & SY2 & 0.03 & 12.56 & 0.87 & 1.40 & 5.36 & 34.48 \\
\hline 24 & SY3 & -15.66 & 95.84 & 1.19 & 6.36 & 12.59 & 188.42 \\
\hline 25 & SY4 & -214.38 & 86.94 & 0.20 & 15.12 & -10.58 & 160.87 \\
\hline 26 & L1 & 0.01 & 28.70 & 1.86 & 2.66 & 5.72 & 46.72 \\
\hline 27 & L2 & 0.00 & 28.21 & 1.18 & 2.37 & 7.76 & 76.51 \\
\hline 28 & L3 & -422.85 & 158.40 & 7.65 & 33.85 & -7.10 & 105.88 \\
\hline 29 & L4 & 0.00 & 17.26 & 2.74 & 2.58 & 1.84 & 4.70 \\
\hline 30 & L5 & -20.70 & 19.40 & -0.01 & 1.92 & -0.96 & 90.75 \\
\hline 31 & L6 & 0.00 & 62.98 & 7.47 & 8.80 & 3.48 & 14.43 \\
\hline 32 & L7 & 0.00 & 348.09 & 11.23 & 29.53 & 8.03 & 77.36 \\
\hline 33 & L8 & 0.02 & 0.58 & 0.17 & 0.10 & 1.18 & 2.21 \\
\hline 34 & L9 & 0.00 & 35.22 & 2.06 & 2.80 & 8.05 & 82.90 \\
\hline 35 & L10 & 0.00 & 4.35 & 0.85 & 0.62 & 1.89 & 6.68 \\
\hline 36 & L11 & 0.00 & 237.64 & 8.96 & 17.59 & 9.33 & 111.91 \\
\hline
\end{tabular}




\section{Empirical Results}

As it mentioned before, in order to balance our sample we restructured sample by taking all "bad" observations and randomly selected $15 \%$ of "good" observations of 1298 observations. In our subsample there are 149 "bad" observations and 157 "good" observations and the subsample is $24 \%$ of total sample. 266 observations of subsample are used for estimating the model and 40 observations of subsample are used for testing the model.

Table 7. Logistic regression Wald forward variable selection results

\begin{tabular}{|c|c|c|c|c|c|c|c|}
\hline & & B & S.S. & Wald & sd & $\mathbf{p}$ & $\operatorname{Exp}(B)$ \\
\hline \multirow{11}{*}{ Step 12(k) } & KSE5 * & 1.081 & 0.263 & 16.908 & 1 & 0 & 2.947 \\
\hline & BK4 $4^{* * *}$ & 6.941 & 3.763 & 3.402 & 1 & 0.065 & 1034.046 \\
\hline & BK5 * & 1.058 & 0.346 & 9.349 & 1 & 0.002 & 2.882 \\
\hline & BK7 ${ }^{* *}$ & -0.379 & 0.166 & 5.185 & 1 & 0.023 & 0.685 \\
\hline & SY2 * & -3.332 & 0.703 & 22.479 & 1 & 0 & 0.036 \\
\hline & L4 * & 1.505 & 0.579 & 6.749 & 1 & 0.009 & 4.503 \\
\hline & L7 * & -1.241 & 0.308 & 16.287 & 1 & 0 & 0.289 \\
\hline & L8 * & 0.656 & 0.159 & 16.929 & 1 & 0 & 1.927 \\
\hline & L10 * & 1.481 & 0.396 & 14.01 & 1 & 0 & 4.398 \\
\hline & L11 * & -1.722 & 0.547 & 9.902 & 1 & 0.002 & 0.179 \\
\hline & Constant & 2.585 & 0.584 & 19.616 & 1 & 0 & 13.27 \\
\hline
\end{tabular}

Note: $(*)$ significant at $1 \%,(* *)$ significant at $5 \%$ and $(* * *)$ significant at $10 \%$

All variables stated under Table 7 are significant. On the other hand, coefficients of BK7 (Cash Flows from Operating and Investment Activities / Total Equity), L7 (Inventory Turnover Rate (Cost of Sales / Inventories) and L11 (Debts Turnover Rate (Cost of Sales / Trade Debts)) are negative and there is an inverse relation between dependent variable and these variables. Besides, coefficients of L8 (Effectiveness Rate $(1 /((1+$ Receivables Turnover Rate) $+(1+$ Inventory Turnover Rate) $))$ is positive and there is a same direction relation between $L 8$ variable and dependent variable. As this is not reasonable on academic/scientific grounds, in other words as same direction relation between $B K 7, L 7$ and $L 11$ variables and firm success; and inverse relation between $L 8$ variable; $B K 7, L 7, L 8$ and $L 11$ variables were not included in model study. Additionally, $\operatorname{Exp}(B)$ (odd) that is calculated for variable BK4 (Assets in Foreign Currency / Liabilities in Foreign Currency) is too high, it is decided to excluded from model study.

In logistic regression model that run by exclusion of variables $B K 7, L 7, L 8, L 11$ and $B K 4$, and that run with 5 statistically and academically/scientifically significant variables (KSE5, BK5, SY2, L4, L10) it has found out that coefficient of L10 (Assets Turnover Rate (Net Sales / Total Assets)) is insignificant. Accordingly, a model consisting of variables KSE5, BK5, SY2 and $L 4$ and excluded variable $L 10$, has formed and the results are stated under Table 8 (See also Appendix 1). All variables are significant which are used in model. As seen from Table 8 all variables have significant coefficient. Both Cox \& Snell and Nagelkerke statistics show that explanatory power of the model is $40.2 \%$ and $53.6 \%$ respectively. It can be concluded that model is significant and valid according to Hosmer and Lemeshow test $(\mathrm{p}=0.903)$.

Table 8. Logistic regression final results

\begin{tabular}{lcccccccc}
\hline & B & S.S. & Wald & sd & p & Exp(B) & \multicolumn{2}{c}{$\operatorname{Exp(B)~Confidence~Interval~}$} \\
\hline KSE5 $^{*}$ & 1.084 & .239 & 20.624 & 1 & .000 & 2.957 & 1.852 & 4.720 \\
BK5 $^{*}$ & 0.947 & .273 & 12.011 & 1 & .001 & 2.577 & 1.509 & 4.402 \\
SY2 & -1.772 & .428 & 17.159 & 1 & .000 & 0.170 & 0.073 & 0.393 \\
L4 $^{*}$ & 1.244 & .340 & 13.410 & 1 & .000 & 3.471 & 1.783 & 6.755 \\
Constant & 1.433 & .269 & 28.322 & 1 & .000 & 4.190 & & \\
\hline
\end{tabular}

Note: $(*)$ significant at $1 \%$,

\begin{tabular}{ccccccc}
\hline & & \multicolumn{5}{c}{ Hosmer and Lemeshow Test } \\
\hline $\mathbf{R}^{\mathbf{2}}$ & Cox and Snell & Nagelkerke & Step & Chi-square & df & Sig. \\
\cline { 2 - 8 } & 0.402 & 0.536 & $\mathbf{1}$ & 3.451 & 8 & 0.903 \\
\hline
\end{tabular}


As it is seen from the Table 8 coefficients of variables KSE5, BK5 and $L 4$ are positive and the coefficient of variable $S Y 2$ is negative which is corresponded with the theory. Hence, it is expected that financial success has negative relation with variable $S Y 2$ and meanwhile positive relation with variables $K S E 5, B K 5$ and $L 4$.

Our estimated logistic regression equation can be stated as follows:

$$
\begin{aligned}
Y=1.433 & +1.084 * \text { KSE } 5+0.947 * \text { BK5 }-1.772 * \text { SY } 2+1.244 * \text { L4 } \\
Y= & 1.433 \\
& +1.084 *(\text { Earnings before Interest, Taxes, Depreciation and Amortization I / Total Assets }) \\
& +0.947 *(\text { Cash Flows from Operating Activities / Total Liabilities }) \\
& -1.772 *(\text { Leverage Ratio (Total Liabilities / Total Assets })) \\
& +1.244 *(\text { Net Sales / Short Term Liabilities })
\end{aligned}
$$

As it known, coefficients of variables calculated in logistic regression do not give accurate information regarding the direct impact of independent variables on dependent variable. To identify impact of independent variables on dependent variable $\operatorname{Exp}(\mathrm{B}) \mathrm{s}$ (odds), that gives proportional result, shall be examined.

As it is seen from the Table 9, our model, which is formed by 4 variables, classifies "bad" firms $77.85 \%$ and classifies "good" firms $76.43 \%$ correctly which results with an overall $77.12 \%$ correct classification.

Table 9. Correct classification percentage of the model that applied subsample

\begin{tabular}{ccccc}
\hline & & \multicolumn{2}{c}{ Predicted Class } & \multirow{2}{c}{$\begin{array}{c}\text { Correct classification } \\
\text { percentage (\%) }\end{array}$} \\
\cline { 3 - 4 } Observed Class & Bad & Good & 77.85 \\
\cline { 3 - 4 } General Correct classification percentage & Bad & 116 & 33 & 76.43 \\
& Good & 37 & 120 & 77.12 \\
\hline
\end{tabular}

Our logistic regression model formed by SPSS 18 Portable Program, is inserted into SPSS Clementine 11.0 and data received have been classified as training sample (266 observations) and testing sample (40 observations). In the graphic below, the uppermost line (blue line) shows correct classification can be made at the most. The area between second graphic line and line which has $45^{\circ}$ angle shows the success of the model.
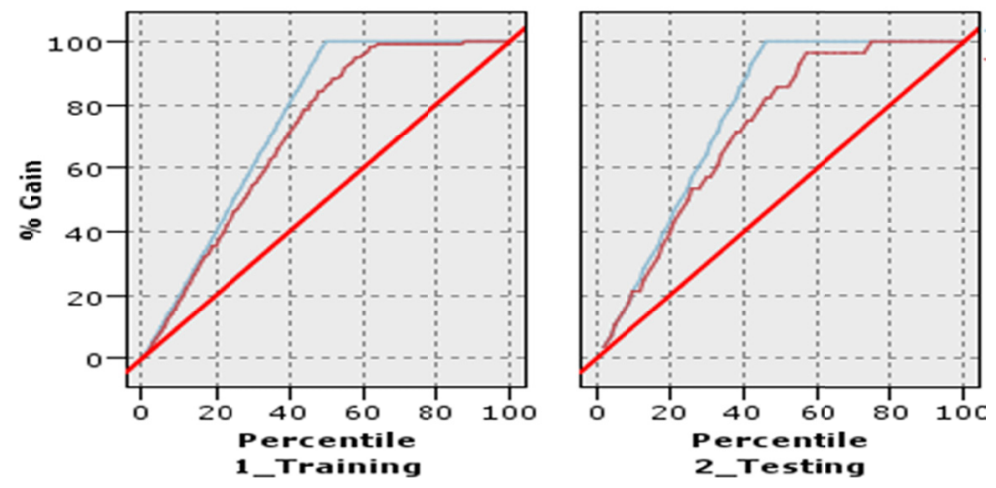

Our logistic regression model run into whole data that contains 1298 observations (149 observations are "bad" and 1149 observations are "good"), $Y$ values has calculated for each observation and success probability is calculated via the formula $\operatorname{Exp}(Y) /(1-\operatorname{Exp}(Y))$. $Y$ values that each observation will take, are predicted by accepting the firms which received probability over 0.50 from calculations as successful "good" and firms which received under the mentioned level from calculations as unsuccessful "bad". Accordingly $Y$ values that predicted via this method were compared with observed $Y$ and the results of correct classification of the model are given under Table 10. 
Table 10. Correct classification percentage of the model that applied to main sample

\begin{tabular}{cccccc}
\hline & \multirow{2}{*}{ Observed } & & Sample & \multicolumn{2}{c}{ Predicted } \\
\cline { 3 - 5 } & & & Total & Bad & Good \\
\cline { 3 - 5 } Observed & \multirow{2}{*}{ Bad } & \# of obs. & 149 & 116 & 33 \\
& & $\%$ & $11.5 \%$ & $\mathbf{7 7 , 8 5 \%}$ & $22.15 \%$ \\
& \multirow{2}{*}{ Good } & $\#$ of obs. & 1149 & 234 & 915 \\
& & $\%$ & $88.5 \%$ & $20,36 \%$ & $\mathbf{7 9 . 6 4 \%}$ \\
\hline
\end{tabular}

Accordingly, it is seen that, our model classifies "bad" firms $77.85 \%$ correctly and classifies "good" firms $79.64 \%$ correctly due to application of the model to whole 1298 samples and overall correct classification success is found as $79.42 \%$.

As mentioned before, logistic regression gives different probability values for each observation. This characteristic of the method enables us to make ad libitum classification of firms regarding their success probability.

Within the scope of this study firms are classified as 5 groups based on the probability values for each observation. The group size, rating grades and the probability tranches are given under Table 11.

Table 11. Rating grades and rating grades distribution of firms in the sample

\begin{tabular}{cccc}
\hline Probability & Grade & \# of observations & Percentage (\%) \\
\hline$>\mathbf{0 . 8 0}$ & $\mathrm{A}$ & 584 & 45 \\
$\mathbf{0 . 6 0 - 0 . 8 0}$ & $\mathrm{B}$ & 246 & 19 \\
$\mathbf{0 . 4 0 - 0 . 6 0}$ & $\mathrm{C}$ & 217 & 17 \\
$\mathbf{0 . 2 0 - 0 . 4 0}$ & $\mathrm{D}$ & 135 & 10 \\
$<\mathbf{0 . 2 0}$ & $\mathrm{E}$ & 116 & 9 \\
\hline TOTAL & & $\mathbf{1 2 9 8}$ & $\mathbf{1 0 0}$ \\
\hline
\end{tabular}

As it is seen from the table, according to probability tranches of being good, firms were rated as follows where A represents the best grade and where E represents the worst. Firms success probability which are

- greater than 0.80 is " $\mathrm{A}$ ",

- greater than 0.60 and less than 0.80 is " $\mathrm{B}$ ",

- greater than 0.40 and less than 0.60 is " $\mathrm{C}$ "

- greater than 0.20 and less than 0.40 is " $D$ "

- less than 0.20 is " $E$ "

\section{Conclusion}

There is no single definition and methodology for corporate rating. Each regulative authority or the rating agency has its' own unique definition and own unique methodology where these are differentiated due to sectors, and regarding the rating of firms or financial instrument. Furthermore, it won't be possible to use same methodology forever that once formed and the rating methodologies have to be reviewed and improved in time.

In this study a model is developed using logistic regression analysis for the forecasting the rating grades of the manufacturing firms that form the basis to expert evaluation. It should be kept in mind that the appointed rating grades developed by models, are not conclusive and they need to be evaluated by the experts in view of the subjective facts.

The status of the firms being "successful/good" or "unsuccessful/bad" based on financial capability is tried to be determined within the study by using more than one defining variables. In other words, our dependent variable consists of two groups. Accordingly, in our study, logistic regression method is used which is one of the most appropriate model that enables a dependent variable to take two values.

The annual financial statements and their notes prepared according to IFRS regarding the period of 2007-2013 of manufacturing firms that are listed in Borsa Istanbul equity market are used. The 206 listed manufacturing firms that are traded in Borsa Istanbul equity market for the whole examination period or a term of it have been selected for the 
sample. Accordingly, publicly disclosed balance sheets, income statements and cash flow statements and their notes of 206 listed firms are collected and 35 financial ratio in 5 groups have calculated. Mentioned ratios form independent values of the study and consist of $88.5 \%$ (1149 observations) that are classified as "good" and $11.5 \%$ (149 observations) that are classified as "bad".

While forming the model instead of using whole observations (149 "bad", 1149 "good" of total 1298 observations), 306 ( 157 "good", 149 "bad") observations which forms circa $24 \%$ of the total data were used. In order to balance our sample remaining observations that belong to good firms were excluded. The model is formed by 266 observations chosen from data that consists of 306 observations and the remaining observations were used for test purposes.

The Wald forward variable selection method is used in order to eliminate highly correlated variables and reduce number of variables and accordingly, ten variable has chosen. Following the application of Wald forward variable selection method, four variables which are scientifically/academically insignificant on the grounds of their relation way's, one variable which is statistically insignificant and one variable which have high calculated $\operatorname{Exp}(B)$ (odd) value are excluded. At the final stage, explanatory model is formed based on four variables (KSE5, BK5, SY2 and L4).

The coefficients of variables KSE5, BK5 and $L 4$ are positive and the coefficient of $S Y 2$ is negative which are consistent with the theory. Hence, financial success is expected to have negative relation with $S Y 2$, meanwhile to have positive relation with $K S E 5, B K 5$ and $L 4$.

The logistic regression model of four variables is applied to whole sample of 1298 observations, $Y$ values are calculated for each observation and probability of being "good" for each observation has calculated by the formula $\operatorname{Exp}(Y) /(1-\operatorname{Exp}(Y))$. By accepting calculated probabilities that are greater than 0.5 as "good" (1) and otherwise as "bad" (0) $Y$ values are predicted. $Y$ values that are predicted and observed were compared and it has found that the model classifies "bad" firms $77.85 \%$ correctly and classifies "good" firms $79.64 \%$ correctly and the classifies overall $79.42 \%$ correctly.

Within the logistic regression model different probability values are calculated for each observation. This feature of the model enabled us to distribute firms depending on tranches of probability. In this study, firms are classified into 5 group based on the probability values for each observation. If the probability of being good is greater than 0.80 then firm's grade is classified as " $\mathrm{A}$ ", if it is greater than 0.60 and less than 0.80 then firm's grade is classified as "B", if it is greater than 0.40 and less than 0.60 then firm's grade is classified as " $C$ ", if it is greater than 0.20 and less than 0.40 then firm's grade is classified as " $\mathrm{D}$ " and if it is less than 0.20 then firm's grade is classified as " $\mathrm{E}$ ", where A group represents the best grade firms and $\mathrm{E}$ group represents the worst grade firms.

As a result, by running the four variable logistic regression model to the datas of a selected firm, $Y$ value of the chosen firm can be calculated with a success ratio of $78 \%-80 \%$, by using the formula $\operatorname{Exp}(Y) /(1-\operatorname{Exp}(Y))$, the probability of being "good"-"bad" of the chosen firm can be determined and rating grade can be given by using a scale that is recommended by us or a scale that will be developped by the users.

It should be kept in mind that the appointed rating grades developed by models, are not final and they need to be evaluated by the expert in view of the facts that are not present in models. Additionally, running model directly to the firm's data may not always result accurately. Users must evaluate the financial reports of the firm on the grounds of fairness and correctness and examine them whether they represent a permanent time-period or not and then give a final rating grade.

\section{References}

Altman, E., \& Katz, S. (1976). Statistical Bond Rating Classification Using Financial and Accounting data. In Michael Schiff \& George Sorter (Eds.), Proceedings of the Conference on Topical Research in Accounting. New York: New York University School of Business.

Bingöl, B. (2009). Türkiye'de Kobi Niteliğinde Faaliyet Gösteren Tekstil Üretim Şirketlerinin Basel II Kriterleri çerçevesinde Kredi Derecelendirme Metodolojisi Uygulanmast. Unpublished PHD's Thesis, Marmara University, Institute of Banking and Insurance, Banking Department, İstanbul.

Borsa İstanbul Corp. Firm Data. Retrieved November 2013-January 2014, from http://www.borsaistanbul.com/veriler/verileralt/hisse-senetleri-piyasasi-verileri/sirketler-verileri

Borsa İstanbul Corp. Firm Disclosures. Retrieved November 2013-January 2014, from http://www.borsaistanbul.com/yatirimcilar/sirket-haberleri-arsiv 
Borsa İstanbul Corp. Markets. Retrieved September 29, 2014, from http://www.borsaistanbul.com/urunler-ve-piyasalar/piyasalar/pay-piyasasi

Boyacıoğlu, M.A. (2003). Bankalarda Derecelendirme (Rating) ve Türk Bankacıllk Sektörü Üzerine Ampirik Bir Çalışma. Unpublished PHD's Thesis, Selçuk University, Institute of Social Sciences, Department of Business Administration, Accounting and Finance, Konya.

Brabazon, A., \& O'Neill, M. (2006). Credit classification using grammatical evolution. Informatica, 30, 325-335.

BRSA. (2012). Regulation on the principles regarding the authorization and activities of rating agencies. Published on 17.04.2012 and numbered 28267 at Official Gazette, 2012, Ankara.

Budak, H., \& Erpolat, S. (2012). Kredi Riski Tahmininde Yapay Sinir Ağları ve Lojistik Regresyon Analizi Karşılaştırması. Online Academic Journal of Information Technology, Autumn, 3(9).

Chaveesuk, R., \& Srivaree-Ratana, C. (1999). Alternative neural network approaches to corporate bond rating. Journal of Engineering Valuation and Cost Analysis, 2, 117-131.

Delahunty, A., \& OCallaghan, D. (2004). Artificial immune systems for the prediction of corporate failure and classification of corporate bond ratings. Dublin: University College Dublin.

Hajek, P. (2010). Credit Rating Modelling by Neural Networks. New York: Nova Science Publishers, Inc.14, 20, 38. http://dx.doi.org/10.1016/j.dss.2010.11.033

Hazar, A. (2009). Firma Riski Derecelendirmesi-Model Önerisi ve Sektörel Uygulama. Unpublished PHD's Thesis, Gazi University Institute of Social Sciences, Department of Business Administration, Accounting and Finance, Ankara, 65, 113-114.

Horrigan, J.O. (1966). The determination of long term credit standing with financial ratios, empirical research in accounting: selected studies. Journal of Accounting Research, 4.

Huang, Z., \& Chen, H. (2004). Credit rating analysis with support vector machines and neural networks: A market comparative study. Decision Support System, 37, 543-558. http://dx.doi.org/10.1016/S0167-9236(03)00086-1

Hwang, C.L., \& Cheng K.F. (2008). On multiple-class prediction of issuer credit ratings. Applied Stochastic Model in Business and Industry, Wiley Interscience. http://dx.doi.org/10.1002/asmb.735

İşman, K. (2009). Basel II Çerçevesinde Kredi Derecelendirme ve İMKB'de İşlem Gören Otomotiv Sektöründeki Bazı Firmalara Uygulanması. Unpublished Master's Thesis, Marmara University, Institute of Banking and Insurance, Capital Markets and Exchanges, İstanbul.

Kadıoğlu, E. (2014). Borsa Istanbul'un Mikro Yapisindaki Değişikliklerin Gün İçi Getiri, Volatilite ve Kapaniş Fiyatina Etkisi. Unpublished PHD's Thesis, Baskent University, Institute of Social Sciences, Department of Business Administration, Accounting and Finance, Ankara.

Kamstra, M., Kennedy, P., \& Suan, T.K. (2001). Combining bond rating forecasts using logit. The Financial Review, 37, 75-96. http://dx.doi.org/10.1111/j.1540-6288.2001.tb00011.x

Kaplan, R.S., \& Urwitz, G. (1979). Statistical models of bond ratings: a methodological inquiry. The Journal of Business, 52(2), 231-261. http://dx.doi.org/10.1086/296045

Keasey, K., \& Watson, R. (1997). Non-Financial Symptoms and the Prediction of Small Company Failure: A Test of Argenti's Hypotheses. Journal of Business Finance Accounting, 14(3), 335-354. http://dx.doi.org/10.1111/j.1468-5957.1987.tb00099.x

Kim, K.S. (2005). Examining corporate bankruptcy: an artificial intelligence approach International. Journal of Business Performance Management, 7(3), 1-1,1.

Maher, J.J., \& Sen, T.K. (1997). Predicting bond ratings using neural networks: a comparison with logistic regression. Intelligent Systems in Accounting, Finance and Management, 6, 59-72. http://dx.doi.org/10.1002/(SICI)1099-1174(199703)6:1\%3C59::AID-ISAF116\%3E3.3.CO;2-8

Moody, J., \& Utans, J. (1995). Architecture selection strategies for neural networks application to corporate bond rating. In A Refenes (Ed.), Neural Networks in Capital Markets (pp. 277-300). Chichester, UK: Wiley.

Öcal, N. (1997). Türkiye'de Menkul Kıymetleştirme Uygulaması, Etkileri, Sorunlar ve Çözüm Önerileri. Master's Thesis, Gazi University, Institute of Social Sciences, Capital Markets Board of Turkey, 106, 25. 
Öcal, N. (2014). Firma Derecelendirmesi ve Borsa İstanbul'da İmalat Sektörü için Model Önerisi. Unpublished PHD's Thesis, Gazi University, Institute of Social Sciences, Department of Business Administration, Accounting and Finance, Ankara.

Özdemir, F.S. (2011). Finansal Başarısızlık ve Finansal Tablolara Dayalı Tahmin Yöntemleri. Ankara: Siyasal Kitapevi, 33-37, 82, 106-108.

Özdinç, Ö. (1999). Derecelendirme Sürecinde Ekonometrik Bir Değerlendirme. Capital Markets Board of Turkey, Ankara.

Pinches, G.E., \& Mingo, K.A. (1973). A multivariate analysis of industrial bond ratings. Journal of Finance, 28(1), 1-18. http://dx.doi.org/10.2307/2978164

Pinches, G.E., \& Mingo, K.A. (1975). The role of subordination and industrial bond ratings. Journal of Finance, 30(1), 201-206. http://dx.doi.org/10.2307/2978442

Pogue, T.F., \& Soldofsky, R.M. (1969). What's in the bond rating?. Journal of Financial and Quantitative Analysis, 4, 201-228.

Public Disclosure Platform. Firm Disclosures. Retrieved November 2013-January 2014, from http://www.kap.gov.tr/bildirim-sorgulari/sirket-haberleri.aspx

Sezgin, Ö. (2006). Statistical Methods in Credit Rating. Unpublished Master's Thesis, Middle East Technical University, Institute of Applied Mathematics, Department of Financial Mathematics, Ankara.

SPK. (2007). Communiqué on the principles regarding rating activity in capital markets and ratings agencies (Serial: VIII, Number: 51). Published on 12.07.2007 and numbered 26580 at official Gazette. 2007, Ankara.

Tatlıdil, H., \& Özel, M. (2005). Firma Derecelendirme Çalışmaları Konusunda Çok Değişkenli İstatistiksel Analize Dayalı Karar Destek Sistemlerinin Kullanımı. Bankactlar Dergisi, 54.

US Securities and Exchange Commission. (2003, January). Report on the role and function of credit rating agencies in the operation of the securities markets. 3-5, 9-10, 21-24, 26-29, 31-41. Retrieved November 11, 2011, from http://www.sec.gov/news/studies/credratingreport0103.pdf

Uzunoğlu, H. (2013). Banka Kredi Derecelendirmesi: Yapay Sinir Ağları Yöntemi ile Türk Bankaları Üzerine Bir Uygulama. Unpublished Master's Thesis, Süleyman Demirel University, Institute of Social Sciences, Department of Business Administration, Isparta.

West, R.R. (1970). An alternative approach to predicting corporate bond rating. Journal of Accounting Research, 8, 118-125.

Yolaş V., \& Serap, N. (2009). Basel Uzlaşısı Çerçevesinde KOBİlerde Kredi Derecelendirme Notu Uygulaması. Unpublished PHD's Thesis, Afyon Kocatepe University, Institute of Social Sciences, Department of Business Administration, Afyonkarahisar, 106.

Yüce, M. (2011). Modeling Internal Credit Ratings of Turkish Companies Listed on the ISE. Unpublished PHD's Thesis. Yeditepe University Institute of Social Sciences, Economics, İstanbul.

\section{Notes}

Note 1. The difference between EBITDA I and EBITDA II is that, EBITDA II consists of termination provisions for severance payment.

Note 2. Although erosion of capital is a quantitative indicators, in our study it is interpreted as whether capital is eroded or not rather than how much eroded. 


\section{Appendices}

Appendix 1. Results of Logistic Regression

Case Processing Summary

\begin{tabular}{cccc}
\hline Unweighted Cases(a) & $\mathbf{N}$ & Percent \\
\hline \multirow{3}{*}{ Selected Cases } & Included in Analysis & 306 & 100 \\
\cline { 2 - 4 } & Missing Cases & 0 & 0 \\
\cline { 2 - 4 } & Total & 306 & 100 \\
\hline Unselected Cases & 0 & 0 \\
\hline \multicolumn{2}{c}{ Total } & 306 & 100 \\
\hline \multirow{2}{*}{ a If weight is in effect, see classification table for the total number of cases. }
\end{tabular}

Dependent Variable Encoding

\begin{tabular}{cc}
\hline Original Value & Internal Value \\
\hline $\mathbf{0}$ & 0 \\
\hline $\mathbf{1}$ & 1 \\
\hline
\end{tabular}

Block 0: Beginning Block

Classification Table(a,b)

\begin{tabular}{|c|c|c|c|c|c|}
\hline & \multirow{3}{*}{ Observed } & & \multicolumn{3}{|c|}{ Predicted } \\
\hline & & & \multicolumn{2}{|c|}{ GOOD1BAD0 } & \multirow{2}{*}{$\begin{array}{c}\text { Percentage Correct } \\
0\end{array}$} \\
\hline & & & $\mathbf{0}$ & 1 & \\
\hline \multirow{3}{*}{ Step 0} & \multirow{2}{*}{ GOOD1BAD0 } & $\mathbf{0}$ & 0 & 149 & 0 \\
\hline & & 1 & 0 & 157 & 1000 \\
\hline & \multicolumn{2}{|c|}{ Overall Percentage } & & & 513 \\
\hline \multicolumn{6}{|c|}{ a Constant is included in the model. } \\
\hline \multicolumn{3}{|c|}{$\mathrm{b}$ The cut value is 0.500} & & & \\
\hline
\end{tabular}

Variables in the Equation

\begin{tabular}{cccccccc}
\hline & B & S.E. & Wald & df & Sig. & Exp(B) \\
\cline { 3 - 7 } & & Lower & Upper & Lower & Upper & Lower & Upper \\
\hline Step 0 & Constant & .052 & .114 & .209 & 1 & .647 & 1.054 \\
\hline
\end{tabular}

Variables not in the Equation

\begin{tabular}{|c|c|c|c|c|c|}
\hline & & & Score & df & Sig. \\
\hline \multirow{5}{*}{ Step 0} & \multirow{4}{*}{ Variables } & KSE5 & 43.426 & 1 & .000 \\
\hline & & BK5 & 19.649 & 1 & .000 \\
\hline & & SY2 & 24.317 & 1 & .000 \\
\hline & & L4 & 60.695 & 1 & .000 \\
\hline & \multicolumn{2}{|c|}{ Overall Statistics } & 91.576 & 4 & .000 \\
\hline
\end{tabular}

Block 1: Method $=$ Enter

Omnibus Tests of Model Coefficients

\begin{tabular}{lcccc}
\hline & & Chi-square & df & Sig. \\
\hline \multirow{3}{*}{ Step 1 } & Step & 157.178 & 4 & .000 \\
\cline { 2 - 5 } & Block & 157.178 & 4 & .000 \\
\cline { 2 - 5 } & Model & 157.178 & 4 & .000 \\
\hline
\end{tabular}


Model Summary

\begin{tabular}{cccc}
\hline Step & $\mathbf{- 2}$ Log likelihood & Cox and Snell R Square & Nagelkerke R Square \\
\hline $\mathbf{1}$ & $266.819(\mathrm{a})$ & .402 & .536 \\
\hline a Estimation terminated at iteration number 7 because parameter estimates changed by less than .001. \\
\hline
\end{tabular}

\begin{tabular}{cccc}
\multicolumn{4}{c}{ Hosmer and Lemeshow Test } \\
\hline Step & Chi-square & df & Sig. \\
\hline 1 & 3.451 & 8 & .903 \\
\hline
\end{tabular}

Contingency Table for Hosmer and Lemeshow Test

\begin{tabular}{|c|c|c|c|c|c|c|}
\hline & & \multicolumn{2}{|c|}{ GOOD1BAD0 = 0} & \multicolumn{2}{|c|}{ GOOD1BAD0 = 1} & \multirow{2}{*}{$\begin{array}{c}\text { Total } \\
\text { Observed }\end{array}$} \\
\hline & & Observed & Expected & Observed & Expected & \\
\hline \multirow{10}{*}{ Step 1} & 1 & 31 & 30.396 & 0 & .604 & 31 \\
\hline & 2 & 27 & 26.492 & 4 & 4.508 & 31 \\
\hline & 3 & 24 & 23.714 & 7 & 7.286 & 31 \\
\hline & 4 & 19 & 20.848 & 12 & 10.152 & 31 \\
\hline & 5 & 15 & 17.117 & 16 & 13.883 & 31 \\
\hline & 6 & 16 & 13.721 & 15 & 17.279 & 31 \\
\hline & 7 & 9 & 9.902 & 22 & 21.098 & 31 \\
\hline & 8 & 7 & 5.328 & 24 & 25.672 & 31 \\
\hline & 9 & 1 & 1.337 & 30 & 29.663 & 31 \\
\hline & 10 & 0 & .146 & 27 & 26.854 & 27 \\
\hline
\end{tabular}

Classification Table(a)

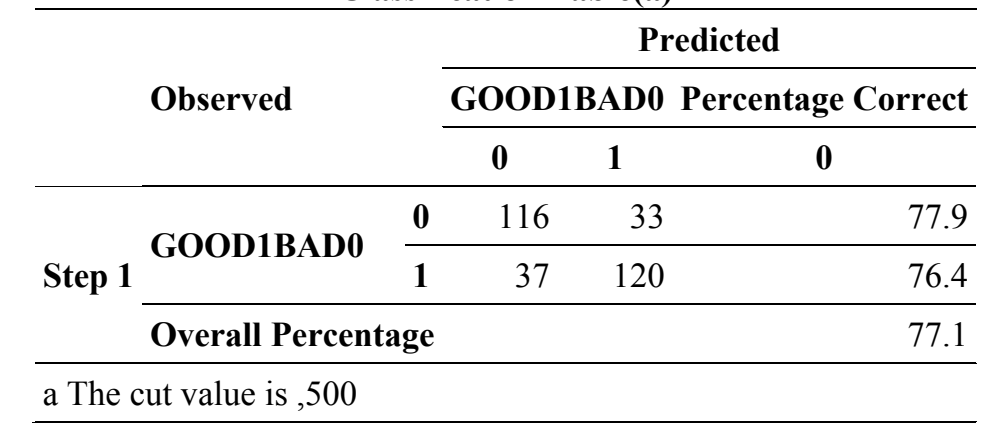

Variables in the Equation

\begin{tabular}{|c|c|c|c|c|c|c|c|c|c|}
\hline & & \multirow{2}{*}{$\begin{array}{c}\text { B } \\
\text { Lower }\end{array}$} & \multirow{2}{*}{$\begin{array}{c}\text { S.E. } \\
\text { Upper }\end{array}$} & \multirow{2}{*}{$\begin{array}{c}\text { Wald } \\
\text { Lower }\end{array}$} & \multirow{2}{*}{$\begin{array}{c}\text { df } \\
\text { Upper }\end{array}$} & \multirow{2}{*}{$\begin{array}{c}\text { Sig. } \\
\text { Lower }\end{array}$} & \multirow{2}{*}{$\begin{array}{l}\operatorname{Exp}(B) \\
\text { Upper }\end{array}$} & \multicolumn{2}{|c|}{ 95,0\% C.I.for EXP(B) } \\
\hline & & & & & & & & Lower & Upper \\
\hline \multirow{5}{*}{ Step 1(a) } & KSE5 & 1.084 & .239 & 20.624 & 1 & .000 & 2.957 & 1.852 & 4.720 \\
\hline & BK5 & .947 & .273 & 12.011 & 1 & .001 & 2.577 & 1.509 & 4.402 \\
\hline & SY2 & -1.772 & .428 & 17.159 & 1 & .000 & .170 & .073 & .393 \\
\hline & L4 & 1.244 & .340 & 13.410 & 1 & .000 & 3.471 & 1.783 & 6.755 \\
\hline & Constant & 1.433 & .269 & 28.322 & 1 & .000 & 4.190 & & \\
\hline
\end{tabular}

a Variable(s) entered on step 1: KSE5, BK5, SY2, L4. 